Counsellia: Jurnal Bimbingan dan Konseling, 10 (2), $2020 \mid 121$ - 134

Copyright (C2020 Universitas PGRI Madiun

ISSN: 2088-3072 (Print) / 2477-5886 (Online)

Available online at: http://e-journal.unipma.ac.id/index.php/JBK

DOI: 10.25273/counsellia.v10i2.6232.

\title{
Hubungan religiusitas, depresi, dan kecemasan Matematika Mahasiswa
}

\author{
Andreas Wisnu Adi Purnomo', J.T. Lobby Loekmono² \\ ${ }^{1}$ Fakultas Keguruan dan Ilmu Pendidikan, Universitas Kristen Satya Wacana, \\ Salatiga \\ andreaswisnu55@gmail.com \\ ${ }^{2}$ Fakultas Keguruan dan Ilmu Pendidikan, Universitas Kristen Satya Wacana, \\ Salatiga \\ lloekmono@yahoo.com
}

\begin{abstract}
Abstrak
Penelitian ini bertujuan untuk mengetahui ada tidaknya hubungan yang signifikan antara variabel religiusitas, depresi dan kecemasan matematika secara bersamaan pada mahasiswa Fakultas Teknik Informatika Universitas Kristen Satya Wacana (FTI UKSW) angkatan 2017 penerima beasiswa dari pemerintah Kabupaten Bengkayang. Penelitian ini berjenis penelitian korelasional dengan jumlah responden sebanyak 34 individu. Teknik sampling yang digunakan adalah Total sampling, yaitu semua populasi dijadikan sampel. Teknik analisis yang digunakan ialah korelasi ganda dengan koefisien signifikansi Sig< 0,05 dinyatakan ada hubungan signifikan. Berdasarkan hasil analisis didapati tidak ada hubungan yang signifikan antara variabel religiusitas, depresi dan kecemasan matematika secara bersamaan. Hal ini dilihat dari koefisien signifikansi korelasi berganda senilai $0,601>0,05$.
\end{abstract}

Kata kunci: Religiusitas, Depresi, dan Kecemasan Matematika

\begin{abstract}
This study aims to determine whether there is a significant relationship between the variables of religiosity, depression and math anxiety simultaneously in the Satya Wacana Christian University (SWCU FTI) Informatics Engineering students class of 2017 who are scholarship recipients from the Bengkayang Regency government. This research is a correlational research type with the number of respondents as many as 34 individuals. The sampling technique used was total sampling, in which all populations were sampled. The analysis technique used is multiple correlation with a significance coefficient of Sig $<0.05$, it is stated that there is a significant relationship. Based on the results of the analysis, it was found that there was no significant relationship between the variables of religiosity, depression and math anxiety simultaneously. This can be seen from the multiple correlation significance coefficient of 0.601>0.05.
\end{abstract}

Keywords: Religiosity, Depression, and Mathematics Anxiety.

\section{PENDAHULUAN}

Kehidupan beragama menjadi hal yang tidak terpisahkan dari masyarakat Indonesia, dimulai sejak Indonesia masih bernama nusantara dan terdiri dari berbagai macam kerajaan, masyarakatnya sudah memeluk agama Hindu sebagai agama yang lebih 
awal dan disusul oleh agama-agama lainnya seperti islam dan kristen. Agama memiliki peran yang penting dalam menata kehidupan masyarakat. Selain peran menata kehidupan masyarakat, agama juga menjadi salah satu sumber nilai moral yang dijadikan pijakan masyarakat untuk bersikap di dalam kehidupannya. Selain itu, agama juga sebagai wadah pemulihan bagi umat yang memeluknya, pemulihan di sini dapat berupa pemulihan secara fisik maupun secara psikis. Pemulihan tersebut salah satunya ialah dengan cara individu yang bersangkutan melakukan perilaku-perilaku keberagamaan seperti pengakuan dosa di hadapan pastur dalam agama kristen (Mc.Leod, 2016), berpuasa dalam agama islam, serta perilaku religius lainnya.

Perilaku-perilaku keberagamaan yang dilakukan oleh individu merupakan salah satu bentuk kesalehan terhadap agama yang dianutnya. Kesalehan individu melakukan ajaran agama yang dipercayainya disebut dengan religiusitas. Menurut Glock and Stark (1970) Religiusitas merupakan keberagamaan yang ditunjukkan dalam bentuk ketaatan serta tanggung jawab individu pada agamanya, yang terlihat melalui perilaku, sikap, tutur kata, serta seluruh aspek kehidupannya mengikuti nilai-nilai yang diajarkan oleh agama yang dianutnya. Dimensi-dimensi dari religiusitas menurut Glock dan Stark (Sari, 2017) terdiri dari: 1) ideological involvement atau keyakinan yang merupakan kepercayaan seseorang terhadap ajaran agama yang dipercayainya serta seberapa besar individu tersebut mempertahankan kepercayaan atas ajaran agama yang dipeluknya. 2) ritual Involvement. Hal ini berkaitan dengan perilaku seseorang dalam melaksanakan ritual keagamaan yang dipeluknya, serta intensitas seseorang dalam melaksanakan tata cara keagamaan yang merupakan upaya memperlihatkan komitmen terhadap agama yang dianutnya. 3) eksperiential involvement atau pengalaman. Hal ini menyinggung tentang pengalaman secara rohani yang membuat individu percaya akan kuasa dan kebenaran Tuhan. 4) Intelektual involvement atau pengetahuan. Hal ini berkaitan dengan pengetahuan dan pemahaman seseorang mengenai ajaran atau nilai-nilai yang harus diimani serta dilaksanakan. 5) Consequential involvement. Hal ini berkaitan dengan perilaku individu yang di latar belakangi motivasi ajaran agama yang dipeluknya dalam kehidupan sosial. Dimensi ini merupakan akibat dari keempat dimensi lain dalam kehidupan sehari-hari individu yang bersangkutan.

Dalam kehidupan serta tanggung jawab melaksanakan ajaran agama yang dipeluknya, individu tidak terlepas dari dinamika kehidupan serta tantangan yang harus dihadapi. Tidak jarang dinamika maupun tantangan kehidupan yang dialami oleh individu membuat individu mengalami permasalahan secara psikologis seperti depresi dan juga kecemasan matematika. Oleh karena itu, individu yang bersangkutan perlu untuk memahami permasalahan psikis yang dialami, dan kemudian menentukan strategi pengentasan problem yang dihadapinya. Depresi didefinisikan sebagai keadaan abnormal individu yang di wujudkan dalam bentuk-bentuk gejala seperti menurunnya mood, adanya rasa pesimis, dan kehilangan spontanitas (Seperti saat kehilangan orang yang dicintai) (Beck, 2011). Depresi juga merupakan gangguan kompleks yang meliputi gangguan afeksi, kognisi motivasi dan komponen perilaku. Selain kondisi emosional yang didera kesedihan yang begitu dalam, individu yang mengalami depresi memiliki pikiran untuk bunuh diri serta ada kecenderungan pada perilaku menyakiti diri sendiri seperti menyayat pergelangan tangan dengan pisau bahkan melakukan tindakan untuk bunuh diri (Beck, 2011). Depresi terjadi akibat faktor-faktor yang saling berpengaruh. Menurut Kremke dan Stremmler (Dirgayunita, 2016) faktorfaktor yang menyebabkan depresi terdiri dari: Biologi, psikologis atau kepribadian dan sosial. Faktor biologi, merupakan faktor melibatkan aktivitas hormon, neurotransmiter, serta sakit fisik dari individu yang berkepanjangan dan membuat individu yang bersangkutan menjadi depresi. Faktor psikologis atau kepribadian, berkaitan dengan 
harga diri individu yang rendah, tidak memiliki sikap asertif, dan menggunakan coping yang tidak tepat, seperti mengkonsumsi alkohol dan rokok berlebihan, menggunakan narkoba sebagai pelarian, maupun memelihara pikiran irasional yang semakin memperlemah kekuatan diri individu yang bersangkutan. Kemudian faktor sosial yang mempengaruhi depresi, berhubungan dengan trauma, peristiwa kehilangan sesuatu yang berharga, tuntutan dari lingkungan sosial yang membuat individu tertekan, maupun kualitas hubungan yang kurang baik dengan individu yang lain.

Sedangkan kecemasan matematika didefinisikan oleh Ashcraft and Faust (1994) sebagai perasaan tegang, gelisah, atau bahkan takut yang mengganggu kegiatan menggunakan angka biasa dan pemecahan masalah matematika. Ketegangan ini berasal dari kegugupan tentang penggunaan alat-alat yang diperlukan dalam kelas matematika (tes, pekerjaan rumah, atau pembelajaran di kelas), atau gugup harus menggunakan angka dalam tugas sehari-hari (menyeimbangkan catatan, mengerjakan tugas yang berhubungan dengan angka). Faktor-faktor yang menjadi latar belakang kecemasan matematika menurut Trujilo dan Hadfield (Syafri, 2017) di antaranya: Faktor kepribadian yang meliputi aspek emosional, seperti rasa rendah diri individu akan kemampuan yang dimilikinya. Selain rasa rendah diri yang dimiliki oleh individu, pengalaman yang tidak menyenangkan dengan pelajaran matematika, membuat individu yang bersangkutan menjadi trauma dengan pelajaran matematika. Faktor yang kedua yang menyebabkan kecemasan matematika adalah lingkungan dan sosial.

Faktor lingkungan dan sosial meliputi kondisi kelas atau tempat belajar ketika sedang mengerjakan atau memahami materi matematika. Selain itu, faktor ini mencakup bagaimana cara guru mengajarkan materi matematika di kelas. Tidak jarang ada guru yang menciptakan suasana kelas yang tegang, sehingga mengakibatkan siswa menjadi tegang dan tidak fokus dalam mempelajari materi matematika di hadapannya. Selain faktor guru yang mengajar, faktor tuntutan dari orang tua terhadap anaknya, supaya mereka pandai matematika, membuat si anak atau individu yang bersangkutan menjadi tertekan. Faktor lainnya yang menyebabkan kecemasan matematika adalah intelektual, setiap individu memiliki bakat dan karunianya masing-masing. Ada yang menguasai keterampilan bermain musik, ada yang handal dalam olahraga, dan ada yang menguasai ilmu matematika. Hal ini tentunya tidak bisa di sama ratakan antara satu individu dengan individu yang lainnya.

Berdasarkan penelitian-penelitian terdahulu yang membahas mengenai variabel religiusitas, depresi dan kecemasan matematika, didapati hasil-hasil penelitian, seperti: Amrai, Zalani, Arfai, and Sharifian (2011) yang melakukan penelitian dengan judul The relationship between the religious orientation and anxiety and depression of students. Penelitian ini bertujuan untuk mengetahui hubungan antara orientasi religius dengan kecemasan dan depresi siswa. Individu yang menjadi sampel dalam penelitian ini terdiri dari 135 laki-laki dan 212 perempuan. Teknik analisis yang digunakan adalah deskriptif deduktif, Annova dan korelasi Pearsons. Berdasarkan hasil penelitian tersebut didapati hasil ada hubungan yang sangat erat antara religiusitas dengan kecemasan dan depresi mahasiswa, dengan arah hubungan yang negatif. Selain itu orientasi keagamaan menurunkan depresi dan kecemasan secara signifikan. Selanjutnya Basri, Hong, Oon, and Kumagai (2015) melakukan penelitian dengan judul Islamic Religiosity, Depression and Anxiety among Muslim Cancer Patients di rumah sakit yang ada di Kuala lumpur Malaysia. Tujuan dari penelitian ini ialah menginvestigasi hubungan antara religiusitas Islam dengan depresi dan kecemasan pada pasien kanker yang beragama muslim. Berdasarkan penelitian tersebut didapati hasil ada hubungan yang signifikan antara religiusitas muslim dengan depresi dan kecemasan dengan arah korelasi negatif. 
Andami (2015) melakukan penelitian dengan tujuan untuk menginvestigasi korelasi antara tingkat religiusitas dengan tingkat depresi, penelitian ini menggunakan desain penelitian cross sectional. Berdasarkan penelitian Andami (2015), didapati hasil ada hubungan yang signifikan antara religiusitas dengan depresi lansia. Selanjutnya Faiz (2014) melakukan penelitian dengan judul Pengaruh Religiusitas Terhadap Tingkat Depresi, Kecemasan, Stres, dan Kualitas Hidup Penderita Penyakit Kronis di Kota Makassar (Kajian Survei Epidemiologi Berbasis Integrasi Islam dan Kesehatan). Tujuan penelitian ini ialah untuk mengetahui hubungan antara religiusitas dan depresi, kecemasan, stres dan kualitas hidup pada penderita penyakit kronis di Makkasar. Berdasarkan hasil penelitian tersebut didapati hasil tidak ada hubungan yang signifikan antara religiusitas dengan depresi penderita penyakit kronis, hal ini dilihat dari nilai signifikansi 0,457 atau $>0,05$, sedangkan hubungan religiusitas dengan kecemasan didapati hubungan yang tidak signifikan dengan nilai signifikansi 0,720 . Penelitian lainnya dilakukan oleh Rohmah (2011) dengan tujuan untuk mengetahui adanya hubungan negatif hubungan antara tingkat religiusitas dengan tingkat depresi lansia di Panti Wredha Dharma Bhakti Surakarta, Berdasarkan penelitian tersebut didapati hasil, ada hubungan dengan arah negatif dengan kategori keeratan kuat antara religiusitas dengan depresi. Kate L Jansen, Motley, and Hovey (2010) meneliti hubungan religiusitas dengan kecemasan dan depresi pada siswa. Berdasarkan penelitian tersebut, didapati hasil religiusitas berhubungan signifikan dengan depresi namun tidak dengan kecemasan. Berdasarkan penelitian yang meneliti hubungan religiusitas dengan kecemasan dan depresi. Dari penelitian tersebut didapati hasil tidak ada hubungan yang signifikan antara religiusitas dengan kecemasan dan depresi.

Kemudian Cogollo, Gómez-Bustamante, Herazo, Oviedo, and Campo-Arias (2013) melakukan penelitian yang bertujuan untuk mengetahui ada tidaknya hubungan yang signifikan antara religiusitas dengan gejala depresi siswa remaja di Cartagena Kolombia. Berdasarkan penelitian Cogollo et al. (2013), di dapati hasil tidak ada hubungan yang signifikan antara religiusitas dengan gejala depresi siswa remaja di Cartagena Kolombia. Berdasarkan penelitian Francis et al. (2019) yang bertujuan untuk mengetahui pengaruh gejala prevalensi depresi dan kecemasan pada mahasiswa kedokteran serta asosiasi antara perilaku coping religius, religiusitas dan hubungan faktor sosio demografi dengan gejala kecemasan dan depresi. Berdasarkan penelitian tersebut didapati hasil, ada hubungan yang signifikan antara coping religius dengan gejala depresi dan kecemasan mahasiswa. Penelitian lainnya yang membahas variabel religiusitas dan kecemasan, dilakukan oleh Shiah, Chang, and Chiang (2015). Penelitian ini berjudul Religion and Health: Anxiety, Religiosity, Meaning of Life and Mental Health, yang bertujuan untuk mengetahui asosiasi antara kecemasan, religiusitas, makna hidup dan kesehatan mental pada masyarakat Tionghoa Taiwan. Penelitian ini berjenis penelitian korelasional. Subjek penelitian terdiri dari 450 individu, yang terdiri dari 150 laki-laki dan 300 perempuan dengan rentang usia 17-73 tahun. Berdasarkan penelitian Shiah et al. (2015), didapati hasil ada hubungan yang signifikan dengan arah negatif antara religiusitas dengan kecemasan.

Berdasarkan uraian hasil penelitian pada paragraf sebelumnya, didapati penelitian yang penulis lakukan memiliki perbedaan dalam hal jenis variabel kecemasan. Penelitian sebelumnya yang dilakukan oleh Francis et al. (2019) ; (Amrai et al., 2011); Andami (2015); Faiz (2014); Kate .L. Jansen (2009); Lupo and Strous (2011), merujuk pada hubungan dan pengaruh antara variabel religiusitas, depresi serta kecemasan secara umum. Sedangkan dalam penelitian ini, variabel kecemasan yang penulis teliti merupakan variabel kecemasan matematika. Selain itu, berdasarkan hasil pencarian jurnal di beberapa alamat jurnal, penulis belum menjumpai penelitian yang memiliki variabel, 
subjek, dan teknik analisis yang sama persis dengan variabel, subjek, serta teknik analisis yang penulis teliti dalam penelitian ini.

Sebelum melakukan penelitian pada subjek (mahasiswa FTI UKSW penerima beasiswa Bengkayang angkatan 2017), peneliti telah melakukan pra penelitian terlebih dahulu. Dalam pra penelitian tersebut peneliti mendapati subjek penelitian dalam kehidupannya di asrama, harus mengikuti kegiatan pembinaan keagamaan yang diadakan oleh pihak asrama. Dalam kegiatan pembinaan tersebut, setiap seminggu sekali diadakan pendalam keagamaan seperti ibadah tiap-tiap unit dan ibadah secara berjamaah satu asrama. Berdasarkan wawancara dengan subjek penelitian, selain mengikuti pembinaan di asrama, subjek penelitian juga mengikuti pendalaman keagamaan di gereja mereka masing-masing, sehingga dalam satu Minggu mereka bisa mengikuti kegiatan pendalaman keagamaan 2-3 kali. Selain daripada itu, berdasarkan pra penelitian yang sudah dilakukan peneliti pada mahasiswa FTI UKSW angkatan 2017 penerima beasiswa Bengkayang dengan cara menyebar inventory depresi Beck dan Abrivarieted Math Anxiety Scale (AMAS) yang telah diuji coba terlebih dahulu serta telah dinyatakan valid. Berdasarkan penyebaran inventori depresi Beck dan AMAS didapati 16 individu masuk kategori normal, sebanyak 5 individu masuk kategori rendah, 7 individu masuk kategori sedang, serta 6 individu masuk kategori berat. Untuk hasil penyebaran AMAS, didapati hasil 3 individu masuk kategori tinggi, 3 individu masuk kategori agak tinggi, 8 kategori sedang, 10 individu masuk kategori cukup rendah, dan 10 individu masuk kategori rendah. Berdasarkan data tersebut, peneliti hendak membuktikan, apakah ada hubungan yang signifikan antara religiusitas subjek penelitian dengan rendahnya tingkat depresi dan kecemasan matematika

\section{METODE PENELITIAN}

\section{Rancangan Penelitian}

Penelitian ini merupakan penelitian korelasional. Menurut Sukmadinata (2005) penelitian korelasional merupakan penelitian yang ditujukan untuk mengetahui hubungan suatu variabel dengan variabel-variabel lainnya. Hubungan antara suatu variabel dengan beberapa variabel dinyatakan dengan besarnya koefisien korelasi dan signifikansi secara statistik.

\section{Sumber Data}

Populasi penelitian berjumlah 34 dan teknik sampling yang digunakan ialah total sampling. Teknik total sampling merupakan teknik pengambilan sampel total sampling adalah teknik pengambilan sampel di mana jumlah sampel sama dengan populasi (Sukmadinata, 2005). Total populasi mahasiswa FTI UKSW penerima beasiswa Pemerintah Bengkayang sebanyak 34 subjek yang terdiri dari individu-individu yang beragama kristen dan islam.

\section{Teknik Pengumpulan Data}

Instrumen penelitian yang digunakan dalam penelitian ini terdiri dari skala religiusitas, yang dibuat oleh Sari (2017) dengan menggunakan teori Glock dan Stark. Selain itu, selain itu item pernyataan pada instrumen yang dibuat oleh Sari (2017) telah di adaptasi oleh peneliti untuk disesuaikan dengan keperluan peneliti. Sedangkan instrumen yang digunakan untuk mengukur depresi, peneliti menggunakan Beck Depression Inventory II (BDI) yang diunduh dari alamat website ismanet.org (Beck, 2011) dan di adaptasi oleh peneliti ke dalam bahasa Indonesia. Kemudian untuk mengukur kecemasan matematika, peneliti menggunakan Abrevarieted Math Anxiety Scale (AMAS) yang dibuat oleh Hopko (2003) kemudian di adaptasi dalam bahasa Indonesia oleh peneliti. 
Instrumen BDI dan AMAS sudah diterjemahkan ke dalam bahasa Indonesia oleh peneliti dan telah dilakukan Back translation oleh saudari Ajeng mahasiswa jurusan sastra Inggris UKSW. Untuk jumlah item pernyataan untuk masing-masing instrumen, didapati Skala religiusitas yang di adaptasi dari penelitian Sari (2017) terdiri dari 18 item pernyataan, dengan pilihan jawaban ya/tidak. Sedangkan untuk Beck Depresion Inventory terdiri dari 21 item pernyataan, yang di masing-masing butir item terdapat 4 pilihan pernyataan yang bisa dipilih. Untuk instrumen (AMAS), terdiri dari 9 item pernyataan.

Berdasarkan hasil uji coba instrumen di dapati skor koefisien Cronbach Alpa atau reliabilitas skala religiusitas senilai $\alpha=0,701(\mathrm{n}=35)$ yang artinya reliabilitas instrumen dapat diterima (Azwar, 2012), sedangkan untuk skor koefisien dari corrected total item correlation skala religiusitas berkisar 0,100 s/d 0,586 $(\mathrm{n}=35)$. Untuk instrumen BDI di dapati skor reliabilitas Cronbach Alpha atau $\alpha=0,903(\mathrm{n}=35)$ yang artinya reliabilitas instrumen sangat bagus (Azwar, 2012), sedangkan untuk skor koefisien dari corrected total item correlation berkisar $0,340 \mathrm{~s} / \mathrm{d} 0,703(\mathrm{n}=35)$. Untuk instrumen (AMAS), di dapati skor koefisien Cronbach Alpha atau reliabilitas senilai 0,853 $(\mathrm{n}=35)$ yang artinya reliabilitas instrumen tersebut bagus (Azwar, 2012), sedangkan untuk skor koefisien dari corrected total item correlation berkisar 0,363 s/d 0,793 $(\mathrm{n}=35)$.

\section{Teknik Analisis Data}

Teknik analisis data hubungan antara variabel religiusitas, depresi dan kecemasan matematika digunakan teknik analisis deskriptif dan analisis statistika. Selain itu data dalam penelitian ini berjenis data ordinal dan juga tidak berdistribusi normal. Oleh karena itu dalam analisis untuk mengetahui hubungan antara variabel religiusitas, depresi, dan kecemasan matematika secara parsial digunakan rumus spearman rho yang dibantu dengan perangkat lunak SPSS versi 16 for windows. Sedangkan Analisis korelasi berganda untuk mengetahui hubungan antara variabel $X$ dengan variabel $Y_{1}$ dan $Y_{2}$ secara simultan, digunakan rumus regresi berganda untuk mengetahui nilai $\mathrm{R}$. Lalu untuk mengetahui nilai signifikansinya, dilakukan perbandingan nilai antara $F_{\text {hitung }}$ dengan $F_{\text {tabel. }}$.

\begin{tabular}{cc} 
Tabel 1. Pedoman Interprestasi Koefisien Korelasi \\
\hline Interval Koefisien & Tingkat Hubungan \\
\hline $0,00-0,199$ & Sangat lemah \\
\hline $0,20-0,399$ & Lemah \\
\hline $0,40-0,599$ & Sedang \\
\hline $0,60-0,799$ & Kuat \\
\hline $0,80-1,00$ & Sangat kuat \\
\hline
\end{tabular}

(Riduwan, 2005).

\section{HASIL DAN PEMBAHASAN}

\section{Hasil Penelitian}

Hasil penelitian disajikan dalam bentuk analisis deskriptif dan statistika. Hasil analisis data dalam bentuk deskriptif disajikan dalam tabel 2, 3, dan 4. Sedangkan untuk analisis korelasi secara parsial variabel $\mathrm{X}$ dengan $\mathrm{Y}_{1}$ dan $\mathrm{Y}_{2}$ ditampilkan pada tabel 5, untuk analisis korelasi berganda akan disajikan pada tabel 6 .

Berdasarkan data pada tabel 2. Didapati jumlah subjek penelitian yang masuk kategori religiusitas dengan tingkat sedang sejumlah 9 individu dengan persentase $26,5 \%$, dan 25 individu masuk kategori tinggi dengan persentase 73,5\%. Berikutnya tabel 3 didapati jumlah subjek penelitian yang masuk kategori depresi normal sebanyak 16 individu dengan persentase 47\%, 5 individu masuk kategori rendah dengan persentase 14,7\%, 7 individu masuk kategori sedang dengan persentase 20,5\%, dan 6 individu masuk kategori berat dengan persentase $17,8 \%$. 
Tabel 2. Kategori Variabel Religiusitas

\begin{tabular}{|c|c|c|c|}
\hline Range & Kategori & Frekuensi & Persentase \\
\hline $4-8$ & Rendah. & 0 & $0 \%$ \\
\hline $9-12$ & Sedang. & 9 & $26,5 \%$ \\
\hline $13-16$ & tinggi. & 25 & $73,5 \%$ \\
\hline \multicolumn{2}{|c|}{ Total } & 34 & $100 \%$ \\
\hline \multicolumn{2}{|c|}{ Mean } & 14,470 & \\
\hline \multicolumn{2}{|c|}{ Standar Deviasi } & 2,4524 & \\
\hline \multicolumn{2}{|c|}{ Minimum } & 7 & \\
\hline \multicolumn{2}{|c|}{ Maksimum } & 18 & \\
\hline
\end{tabular}

Tabel 3. Kategori Variabel Depresi

\begin{tabular}{cccc}
\hline Range & Kategori & Frekuensi & Persentase \\
\hline $0-9$ & Normal & 16 & $47 \%$ \\
\hline $10-15$ & Rendah & 5 & $14,7 \%$ \\
\hline $16-23$ & Sedang & 7 & $20,5 \%$ \\
\hline $24>$ & Berat & 6 & $17,8 \%$ \\
\hline & Total & 34 & $100 \%$ \\
\hline Mean & 13.941 & \\
\hline & Standar Deviasi & 12.070 & \\
\hline Minimum & 0 & \\
\hline & Maksimum & 42.00 \\
\hline
\end{tabular}

Berdasarkan tabel 4. Didapati jumlah subjek penelitian yang masuk kategori kecemasan matematika rendah sebanyak 10 individu dengan persentase 29,4\%, 10 individu masuk kategori cukup rendah, dengan persentase 29,4\%, 8 individu masuk kategori sedang dengan persentase $23,5 \%, 3$ individu dengan kategori agak tinggi, persentase $9,35 \%$, dan 3 individu sisanya masuk kategori tinggi dengan persentase $9,35 \%$.

Tabel 4. Kategori Variabel Kecemasan Matematika

\begin{tabular}{cccc}
\hline Range & Kategori & Frekuensi & Persentase \\
\hline $8-12$ & Rendah & 10 & $29,4 \%$ \\
\hline $13-17$ & Cukup rendah & 10 & $29,4 \%$ \\
\hline $18-22$ & Sedang & 8 & $23,5 \%$ \\
\hline $23-27$ & Agak tinggi & 3 & $9,35 \%$ \\
\hline $28>$ & Tinggi & 3 & $9,35 \%$ \\
\hline & Total & 34 & $100 \%$ \\
\hline Mean & 16.617 \\
\hline & Standar deviasi & 5.694 & \\
\hline Minimum & 9.00 & \\
\hline & Maksimum & 29.00 & \\
\hline
\end{tabular}

Tabel 5. Analisis korelasi secara parsial.

\begin{tabular}{lcc}
\hline \multicolumn{1}{c}{ Variabel } & Koefisien Korelasi & Nilai Signifikansi (2-tailed) \\
\hline Religiusitas dengan depresi & -0.114 & 0.522 \\
\hline $\begin{array}{l}\text { Religiusitas dengan kecemasan } \\
\text { matematika. }\end{array}$ & -0.208 & 0.238 \\
\hline Depresi dengan kecemasan matematika. & 0.473 & 0.005 \\
\hline Jumlah Sampel & \multicolumn{2}{c}{ 34 Responden. } \\
\hline
\end{tabular}

Berdasarkan Tabel 5. Didapati koefisien korelasi antara variabel religiusitas dengan depresi sebesar -0,114 yang artinya arah hubungan antara religiusitas dengan depresi bertolak belakang dengan kategori keeratan sangat lemah. Koefisien korelasi 
antara religiusitas dengan kecemasan matematika sebesar -0,208 yang artinya arah hubungan antara variabel religiusitas dengan kecemasan matematika bertolak belakang dan memiliki tingkat keeratan masuk kategori lemah. Sedangkan untuk hubungan antara depresi dan kecemasan matematika didapati nilai koefisien korelasi sebesar 0,473 yang artinya keeratan hubungan antara depresi dengan kecemasan matematika masuk dalam kategori sedang dengan arah yang positif, yaitu semakin tinggi tingkat depresi seseorang, akan diikuti dengan kecemasan matematika yang tinggi juga, demikian juga sebaliknya. Sedangkan nilai sig. hubungan antara depresi dan kecemasan matematika sebesar. 0,005 atau $<0,05$; yang artinya ada hubungan yang signifikan antara depresi dengan kecemasan matematika.

Tabel 6. Analisis Korelasi Berganda

\begin{tabular}{lcc}
\hline \multicolumn{1}{c}{ Variabel } & Koefisien Korelasi Ganda & $\begin{array}{c}\text { Nilai Signifikansi Korelasi } \\
\text { Ganda }\end{array}$ \\
\hline $\begin{array}{l}\text { Religiusitas, depresi dan } \\
\text { kecemasan matematika. }\end{array}$ & 0.180 & 0.601 \\
\hline
\end{tabular}

Berdasarkan Tabel 6. didapati hasil koefisien korelasi ganda antara variabel religiusitas, depresi dan kecemasan matematika secara simultan sebesar 0.180 , yang artinya keeratan hubungan antara ketiga variabel secara bersamaan masuk kategori sangat lemah. Sedangkan untuk nilai Signifikansi hubungan didapati nilai sigi. 0.601 atau $>0,05$ sehingga dapat disimpulkan tidak ada hubungan yang signifikan antara variabel religiusitas, depresi dan kecemasan matematika secara bersamaan.

\section{Pembahasan}

Melihat landasan dasar Bimbingan dan konseling (BK), yang salah satu landasannya ialah landasan religius (Prayitno \& Amti, 2004), tentunya dalam memberikan layanan BK patut memperhatikan serta mengembangkan aspek religius dari konseli yang bersangkutan, selain itu dalam Standar Kompetensi Kemandirian Peserta Didik (SKKPD) dalam Depdiknas (2007) terdapat kompetensi kemdirian landasan hidup religius yang harus dicapai oleh peserta didik, dan hal ini tentunya menjadi keharusan layanan BK untuk membantu peserta didik mencapai taraf kemandirian dalam aspek tersebut. Religiusitas merupakan keberagamaan yang ditunjukkan dalam bentuk ketaatan serta tanggung jawab individu pada agamanya, yang terlihat melalui perilaku, sikap, tutur kata, serta seluruh aspek kehidupannya mengikuti nilai-nilai yang diajarkan oleh agama yang dianutnya (Glock \& Stark, 1970). Religiusitas tidak dapat dipisahkan dengan spiritualitas, keduanya merupakan digunakan secara bergantian dalam literatur-literatur ilmu teologi, namun memiliki perbedaan (Mattis, 2000).

Berdyaev; Chaffers; MacQuarrie (dalam Mattis, 2000) menjelaskan spiritualitas berasal dari kata latin spiritus, yang berarti "nafas kehidupan". Merujuk pada injil perjanjian lama kitab kejadian 2:7, yang tertulis "Tuhan Allah membentuk manusia dari debu tanah dan menghembuskan nafasnya lubang nafas kehidupan, dan manusia menjadi makhluk hidup." Bagian ini secara eksplisit membedakan antara keberadaan fisik (yaitu, tubuh) dan kekuatan yang lebih halus (yaitu, nafas kehidupan) yang keduanya melambangkan hidup dan kelahiran. Berdasarkan penafsiran kitab kejadian 2:7 dalam penelitian Mattis (2000) spiritualitas dapat diartikan sebagai suatu hubungan antara Tuhan dan manusia. Lebih khusus lagi, bagian teks ini menunjukkan bahwa spiritualitas dapat didefinisikan sebagai kehadiran aktif ilahi dalam kehidupan manusia. Pendapat lainnya, yaitu dari Tart (Mattis, 2000) mendefinisikan spiritualitas sebagai potensi manusia yang berhubungan dengan tujuan akhir, entitas yang lebih tinggi, Tuhan, 
kehidupan, dan belas kasih. Definisi spiritualitas Tart mengaitkan spiritualitas dengan kekuatan transenden, makna hidup, dan nilai-nilai sosial yang fundamental.

Berdasarkan penjelasan Berdyaev; Chaffers; MacQuarrie dan Tart (Mattis, 2000), spiritualitas merujuk pada pemaknaan akan kehidupan, keterlibatan aktif Tuhan, potensi manusia untuk mencapai tujuan akhirnya, posisi manusia sebagai entitas dengan hal yang transeden. Selain itu, spiritualitas lebih merujuk pada nilai-nilai yang sifatnya universal. Hal ini terlihat dalam penjelasan Tart (Mattis, 2000) "spiritualitas sebagai potensi manusia yang berhubungan dengan tujuan akhir, entitas yang lebih tinggi, Tuhan, kehidupan, dan belas kasih". Seseorang mampu bertahan menjalani dinamika hidupnya karena ada kekuatan yang ada dalam dirinya, dan kekuatan tersebut merupakan dimensi spiritualitas (Nelson, Rosenfeld, Breitbart, \& Galietta, 2002) . Salah satu cara seseorang menemukan makna hidup adalah melalui agama yang dipercayainya serta dengan melakukan ajaran agamanya seperti datang ke rumah ibadat, berbakti pada orang lain, menjalankan ajaran-ajaran agama yang ditetapkan.

Menurut Glock dan Stark (Sari, 2017) terdapat empat hal yang mempengaruhi religiusitas individu, yaitu: perkembangan pikiran, emosi, sosial, dan moral. Faktor-faktor tersebut dijelaskan sebagai berikut: Perkembangan pikiran individu. Terwujud dalam bentuk kata-kata yang digunakan sebagai alat untuk membedakan yang apa benar dan yang salah. Perkembangan emosi, berkaitan dengan momen-momen yang dialami individu dalam hidupnya yang membuat individu merasakan berbagai macam emosi atau perasaan seperti senang, sedih, kecewa, duka, yang membuat individu semakin teguh atau rapuh dengan agama yang dianutnya. Faktor perkembangan sosial individu berhubungan dengan interaksi individu dengan individu lainnya dalam lingkungan sosial, di mana interaksi tersebut ikut ambil bagian dalam membuat individu semakin teguh atau tidak terhadap agama yang dianutnya. Perkembangan moral, merupakan aspek yang berkaitan dengan pengalaman akan nilai yang dianggap baik atau buruk oleh individu dalam kehidupannya dan secara tidak langsung turut berperan dalam pembentukan religiusitas individu yang bersangkutan. Ditinjau dari segi usia subjek penelitian yang berusia 20-23 tahun, dapat dikatakan subjek penelitian sedang berada pada usia dewasa awal (Santrock, 2002). Dewasa awal merupakan masa transisi dari masa remaja yang meliputi aspek fisik, intelektual dan peran sosial (Santrock, 2002).

Selain itu Hurlock (1999) menjelaskan salah satu karakteristik dari masa dewasa awal ialah penyesuaian diri dengan cara hidup baru. Masa dewasa awal merupakan masa transisi dari masa remaja menuju dewasa. Menurut Jeffrey Arnett (Ayriza) masa ini memiliki ciri-ciri seperti eksplorasi identitas, ketidakstabilan, fokus diri, perasaan tidak sebagai remaja lagi namun juga belum menjadi dewasa, dan usia yang semakin beranjak. Dapat disimpulkan pada masa ini, individu mengalami penyesuaian dan dinamika berkaitan dengan fisik, intelektual serta peran sosialnya, dan hal ini berpengaruh pada religiusitas individu. Ditinjau dari perspektif teori perkembangan iman Fowler (1995), Individu yang menjadi sampel dalam penelitian ini sedang berada pada tahap "kepercayaan individuatif-reflektif", pada masa ini individu yang bersangkutan berada pada masa dewasa awal secara usia dan masa ini ditandai dengan pemikiran reflektif kritis terhadap seluruh asumsi, keyakinan, dan nilai religius lama yang telah mapan. Individu yang berada pada tahap perkembangan iman ini sudah mampu untuk mengamati dirinya sendiri dan orang lain sebagai bagian dari kesatuan sistem kemasyarakatan, tetapi juga sebagai makhluk individual yang memikul tanggung jawab atas ideologi dan Life style yang dipilihnya untuk menjalankan fungsinya di masyarakat. Pada tahap ini pula, individu menyadari bahwa sistem yang ada sebelumnya diyakini perlu dibingkai ulang dan diperbaharui supaya menjadi sebuah sistem yang lebih adaptif bagi dirinya. 
Berdasarkan teori perkembangan iman Fowler (1995), dapat dikatakan tidak didapatinya hubungan yang signifikan antara religiusitas dengan depresi dan kecemasan matematika mahasiswa FTI UKSW angkatan 2017 penerima beasiswa Pemerintah Bengkayang dikarenakan individu yang menjadi subjek sedang pada tahap perkembangan iman "kepercayaan individuatif- reflektif", di mana individu pada tahap ini sedang menyusun ulang kerangka iman yang dipercayainya, dan hal ini berdampak pada bagaimana individu yang bersangkutan memberi tanggapan dan beradaptasi dengan situasi yang sedang di alaminya. Tidak menutup kemungkinan, keberagamaan individu yang diperlihatkan dengan perilaku, sikap, tutur kata, serta seluruh aspek kehidupannya yang mengikuti nilai-nilai yang diajarkan oleh agama yang dianutnya, merupakan suatu cara bagi individu yang sedang pada masa dewasa awal untuk mencari makna hidupnya pada masa perkembangannya hidupnya yang baru.

Berdasarkan hasil penelitian yang telah dilakukan dalam penelitian ini, penulis menemukan temuan-temuan seperti didapati hubungan yang signifikan antara depresi dengan kecemasan matematika yang dialami oleh mahasiswa FTI UKSW penerima beasiswa Pemerintah Bengkayang dengan arah yang positif, yang mana jika individu mengalami depresi akan diikuti juga dengan kecemasan matematika. Selain itu didapati temuan tidak adanya hubungan yang signifikan antara religiusitas dengan depresi, serta tidak ada hubungan yang signifikan antara religiusitas dengan kecemasan matematika pada mahasiswa FTI UKSW penerima beasiswa Pemerintah Bengkayang. Tidak adanya hubungan yang signifikan antara religiusitas, depresi dan kecemasan matematika pada penelitian ini, sejalan dengan hasil penelitian Faiz (2014) yang mengkaji pengaruh Religiusitas Terhadap Tingkat Depresi, Kecemasan, Stres, Dan Kualitas Hidup Penderita Penyakit Kronis Di Kota Makassar. Hasil penelitian yang dilakukan oleh Faiz (2014) didapati hasil, tidak ada hubungan yang signifikan antara religiusitas dengan depresi penderita penyakit kronis, hal ini dilihat dari nilai signifikansi 0,457 atau >0,05, sedangkan hubungan religiusitas dengan kecemasan didapati hubungan yang tidak signifikan dengan nilai signifikansi 0,720 . Selain religiusitas, aspek yang lain yang perlu diperhatikan dalam kehidupan individu adalah aspek spiritualitas. Hal ini didasarkan pada penelitian Nelson et al. (2002), yang menunjukkan hasil, tingginya spiritualitas seseorang lebih berpengaruh untuk mengatasi kecemasan dan depresi dari pada tingkat religiusitas seseorang. Hal ini mengindikasikan adanya pengaruh dari aspek spiritualitas untuk mengatasi gangguan psikis yang dialami oleh individu.

Berdasarkan temuan dalam penelitian ini, didapati hasil yang sejalan dengan hasilhasil penelitian sebelumnya, seperti penelitian yang dilakukan oleh Zakiyyah (2017) dengan judul hubungan religiusitas dan persepsi siswa terhadap guru dengan kecemasan menghadapi pelajaran matematika. Tujuan penelitian ini adalah mengetahui hubungan antara religiusitas dan persepsi siswa terhadap guru dengan kecemasan menghadapi pelajaran matematika. Sampel penelitian berjumlah 58 individu. Teknik pengambilan sampel yang digunakan adalah simple random sampling. Rumus analisis yang digunakan adalah spearman rho dengan taraf signifikansi $5 \%$. Didapati nilai rxy antara religiusitas dengan kecemasan menghadapi pelajaran matematika sebesar $-0,232$, yang artinya ada hubungan yang bertolak belakang dengan kategori keeratan hubungan lemah. Sedangkan signifikansi hubungan antara religiusitas dengan kecemasan menghadapi pelajaran matematika dilakukan dengan membandingkan $F_{\text {hitung }}$ dengan $F_{\text {tabel }}$ dan didapati $1,785<2,000$. Sehingga disimpulkan tidak ada hubungan yang signifikan antara religiusitas dengan kecemasan matematika siswa. Penelitian lainnya yang dilakukan oleh Cogollo et al. (2013) dengan tujuan untuk mengetahui ada tidaknya hubungan yang signifikan antara religositas dengan gejala depresi siswa remaja di Cartagena Kolombia. Penelitian ini berjenis cross sectional dengan rentang usia subjek penelitian antara 13-17 
tahun, teknik analisis yang digunakan ialah product moment Pearson's, berdasarkan penelitian tersebut, di dapati hasil tidak ada hubungan yang signifikan antara religiusitas dengan gejala depresi siswa remaja di Cartagena Kolombia. Lupo and Strous (2011) mengkaji hubungan religiusitas dengan kecemasan dan depresi. Penelitian ini bertujuan untuk mengukur hubungan antara religositas dengan depresi dan kecemasan mahasiswa jurusan medis, selain itu berjenis penelitian Cross sectional dengan jumlah sampel sebanyak 119 individu dan teknik analisis yang digunakan ialah product moment Pearson's. Berdasarkan penelitian Lupo dan Strous didapati hasil tidak ada hubungan yang signifikan antara religositas dengan kecemasan dan depresi.

Pada sisi yang lain hasil penelitian yang disajikan dalam penelitian ini, bertolak belakang dengan hasil-hasil dari penelitian sebelumnya seperti, Rohmah (2011) yang melakukan penelitian dengan tujuan untuk mengetahui adanya hubungan negatif hubungan antara tingkat religiusitas dengan tingkat depresi lansia di Panti Wredha Dharma Bhakti Surakarta, penelitian ini berjenis penelitian observasional analitikal dengan pendekatan belah lintang (cross-sectional). Jumlah subjek penelitian sebanyak 24 individu yang terdiri dari 10 perempuan dan 14 laki-laki, dengan rentang usia 60-80 tahun dengan agama islam, dapat berkomunikasi verbal, dan bersedia menjadi responden, dan teknik analisis yang digunakan ialah product moment Pearson's, berdasarkan penelitian tersebut didapati hasil, ada hubungan dengan arah negatif dengan kategori keeratan kuat antara religositas dengan depresi. Andami (2015) melakukan penelitian dengan tujuan untuk menginvestigasi korelasi antara tingkat religiusitas dengan tingkat depresi, penelitian ini menggunakan desain penelitian cross sectional. Jumlah sampel penelitian terdiri dari 61 subjek. Sampel diambil menggunakan teknik purposive sampling. Analisis data yang dilakukan menggunakan teknik analisis statistik univariat dan bivariat dengan rumus uji korelasi Spearman Rank. Berdasarkan penelitian didapati hasil ada hubungan yang signifikan antara religositas dengan depresi lansia.

Francis et al. (2019) dalam penelitiannya untuk mengetahui pengaruh gejala prevalensi depresi dan kecemasan pada mahasiswa kedokteran serta asosiasi antara perilaku coping religius, religositas dan hubungan faktor sosio demografi dengan gejala kecemasan dan depresi dengan jumlah sampel sebanyak 622 mahasiswa yang beragama islam. Berdasarkan penelitian ini didapati hasil ada hubungan yang signifikan antara coping religius dengan arah yang negatif antara coping religius dengan gejala depresi dan kecemasan mahasiswa. Kemudian Shiah et al. (2015) melakukan kajian dengan tujuan untuk mengetahui asosiasi antara kecemasan, religositas, makna hidup dan kesehatan mental pada masyarakat Tionghoa Taiwan. Penelitian ini berjenis penelitian korelasional. Subjek penelitian terdiri dari 450 individu, yang terdiri dari 150 laki-laki dan 300 perempuan dengan rentang usia 17-73 tahun. Berdasarkan penelitian ini didapati hasil ada hubungan yang signifikan dengan arah negatif antara religiusitas dengan kecemasan. Ditinjau dari aspek subjek penelitian, jenis penelitian, teknik analisis, serta jumlah sampel, terdapat perbedaan antara penelitian Rohmah (2011); Andami (2015); Francis et al. (2019); Shiah et al. (2015), dengan penelitian yang penulis lakukan, membuka kemungkinan terjadinya perbedaan hasil penelitian.

Mengacu pada hasil penelitian Francis et al. (2019) yang menunjukkan tingginya tingkat spiritualitas lebih berpengaruh dalam menurunkan depresi dan kecemasan daripada religiusitas, mengindikasikan bahwa terdapat aspek lain selain religiusitas yang patut untuk dipertimbangkan dalam memberikan layanan. Hal ini bukan berarti mengabaikan aspek religiusitas dari individu, karena religiusitas dan spiritualitas merupakan entitas yang memainkan peran yang berbeda dalam kehidupan individu. Spiritualitas lebih condong pada pengalaman personal seseorang dengan Sang 
Transenden (Tuhan), sedangkan religiusitas berkaitan agama yang cenderung bersifat komunal karena menjadi wadah bagi individu-individu yang mempercayai keyakinan tertentu (Carroll, 1998). Bimbingan dan Konseling sebagai ilmu memiliki salah satu landasan yang sangat erat kaitannya dengan religiusitas, yaitu landasan religius. Landasan religius bimbingan dan konseling secara fundamental berupaya menetapkan konseli atau siswa sebagai makhluk Tuhan dengan segenap kemuliaannya serta menjadi fokus sentral upaya bimbingan dan konseling memberikan layanan pada konselinya (Prayitno \& Amti, 2004). Oleh karena itu, pengembangan layanan BK yang memperhatikan aspek spiritualitas menjadi hal yang penting agar kompetensi kemandirian hidup religius peserta didik dapat bertumbuh secara optimal.

\section{SIMPULAN}

Berdasarkan penelitian yang telah dilakukan, didapati hasil tidak ada hubungan yang signifikan secara simultan antara religiusitas, depresi dan kecemasan matematika mahasiswa FTI UKSW angkatan 2017 penerima beasiswa dari pemerintah Bengkayang. Temuan lain dalam penelitian ini adalah adanya hubungan yang signifikan antara antara variabel depresi dengan kecemasan matematika dengan arah yang positif yang artinya semakin tinggi depresi akan diikuti dengan kecemasan matematika tinggi demikian juga sebaliknya. Hal ini dapat menjadi salah satu dugaan bagi tenaga pendidik, bahwa siswa atau individu yang mengalami kecemasan matematika, ada kemungkinan diikuti dengan gangguan psikis lainnya, salah satunya depresi. Selain itu didapati temuan lainnya yaitu tidak ada hubungan yang signifikan antara religiusitas dengan depresi serta tidak ada hubungan yang signifikan antara religiusitas dengan kecemasan matematika. Oleh karena itu, dalam rangka membantu peserta didik menguasai kompetensi kemandirian hidup religius, layanan BK perlu memperhatikan aspek lain yang menjadi kesatuan dari aspek religius peserta didik, aspek tersebut salah satunya adalah spiritualitas.

\section{UCAPAN TERIMAKASIH}

Ucapan terima kasih saya haturkan kepada yayasan pendidikan BPK Penabur, yang telah mendukung dalam hal dana dalam penelitian. Tanpa dukungan dari pihak BPK Penabur, penelitian ini tidak dapat berjalan sebagaimana adanya.

\section{DAFTAR PUSTAKA}

Amrai, K., Zalani, H. A., Arfai, F. S., \& Sharifian, M. S. (2011). The relationship between the religious orientation and anxiety and depression of students. Procedia-Social and Behavioral Sciences, 15, 613-616.

Andami, R. (2015). Hubungan Tingkat Religositas dengan Tingkat Depresi Lansia Beragama Islam di Panti Tresna Werdha Budi Mulia 4 Margaguna Jakarta Selatan. repository.uinjkt.ac.id.

Ashcraft, M. H., \& Faust, M. W. (1994). Mathematics anxiety and mental arithmetic performance: An exploratory investigation. Cognition \& Emotion, 8(2), 97-125.

Ayriza, R. E. I. Y.). Perkembangan Fisik dan Kognitif Masa Dewasa Awal Retrieved 5 Mei, 2020, from http://staff.uny.ac.id/sites/default/files/pendidikan/dr-rita-ekaizzaty-spsi-msi/gperkembangan-fisik-dan-kognitif-masa-dewasa-awal.pdf

Azwar, S. (2012). Reliabilitas dan Validitas (4 ed.). Yogyakarta: Pustaka Pelajar.

Basri, N. A., Hong, G. C., Oon, N. L., \& Kumagai, S. (2015). Islamic religiosity, depression and anxiety among muslim cancer patients. IAFOR Journal of Psychology \& the Behavioral Sciences, 1(1), 1-12. 
Beck, J. S. (2011). Cognitif Behavior Therapy: Basic And Beyond. (2 ed.). New York: The Guilford Press.

Carroll, M. M. (1998). Social work's conceptualization of spirituality. Social Thought, $18(2), 1-13$.

Cogollo, Z., Gómez-Bustamante, E. M., Herazo, E., Oviedo, H. C., \& Campo-Arias, A. (2013). Association between religiosity and depressive symptoms. Duazary, 10(1), 15-19.

Depdiknas. (2007). Rambu-Rambu Penyelenggaraan Bimbingan dan Konseling dalam Jalur Pendidikan Formal. Jakarta.

Dirgayunita, A. (2016). Depresi: Ciri, Penyebab dan Penanganannya. Journal An-nafs: Kajian dan Penelitian Psikologi, 1(1), 1-14.

Faiz, M. (2014). Pengaruh Religositas Terhadap Tingkat Depresi, Kecemasan, Stres, Dan Kualitas Hidup Penderita Penyakit Kronis Di Kota Makassar (Kajian Survei Epidemiologi Berbasis Integrasi Islam Dan Kesehatan). journal.uinalauddin.ac.id.

Fowler, J. W. (1995). Teori Perkembangan Kepercayaan (A. Cremers, Trans. 1 ed.). Yogyakarta: Kanisius.

Francis, B., Gill, J. S., Yit Han, N., Petrus, C. F., Azhar, F. L., Ahmad Sabki, Z., . . Sulaiman, A. H. (2019). Religious coping, religiosity, depression and anxiety among medical students in a multi-religious setting. International journal of environmental research and public health, 16(2), 259.

Glock, C. Y., \& Stark, R. (1970). Religion and society in tension: a publi. from the research program in the Sociology of Religion Survey Research Center, Univ. of Calif., Berkeley.

Hopko, D. R. (2003). Confirmatory factor analysis of the math anxiety rating scalerevised. Educational and psychological measurement, 63(2), 336-351.

Hurlock, E. B. (1999). Psikologi Perkembangan: Suatu Pendekatan Sepanjang Rentang Kehidupan (I. Soedjarwo, Trans.). Jakarta: Erlangga.

Jansen, K. L. (2009). Anxiety, Depression, and Students Religiosity. Mental Health, Religion, and Culture, 13(3), 267-271. doi: http://dx.doi.org/10.1080/13674670903352837

Jansen, K. L., Motley, R., \& Hovey, J. (2010). Anxiety, depression and students' religiosity. Mental Health, Religion \& Culture, 13(3), 267-271.

Lupo, M. K., \& Strous, R. D. (2011). Religiosity, anxiety and depression among Israeli medical students. Isr Med Assoc J, 13(10), 613-618.

Mattis, J. S. (2000). African American women's definitions of spirituality and religiosity. Journal of black psychology, 26(1), 101-122.

Mc.Leod, J. (2016). Pengantar Konseling dan Studi Kasus (A. K. Anwar, Trans. 3 ed.). Jakarta: Prenada Media Grup.

Nelson, C. J., Rosenfeld, B., Breitbart, W., \& Galietta, M. (2002). Spirituality, religion, and depression in the terminally ill. Psychosomatics, 43(3), 213-220.

Prayitno, \& Amti, E. (2004). Dasar-dasar konseling: Jakarta: PTAsdi Mahasatya.

Riduwan. (2005). Belajar Mudah Penelitian untuk Guru, Karyawan, dan Peneliti Pemula (1 ed.). Bandung: Alfabeta.

Rohmah, M. F. (2011). Hubungan Antara Tingkat Religiusitas dan Tingkat Depresi pada Lansia di Panti Wredha Dharma Bhakti Surakarta. eprints.ums.ac.id.

Santrock, J. W. (2002). Life-Span Development, Perkembangan Masa Hidup (J. D. Achmad Chusair, Trans.). Jakarta: Erlangga.

Sari, N. A. (2017). Hubungan antara Religiusitas dengan Kecemasan terhadap Kematian pada Individu Setengah Baya Desa Randusari. repository.uksw.edu. 
134 | Jurnal Ilmiah Counsellia, Volume 10 No.2, November 2020| 121 - 134

Shiah, Y. J., Chang, F., \& Chiang, S.-K. (2015). Religion and Health: Anxiety, Religiosity, Meaning of Life and Mental Health. Springer Science \& Business, 54, 35-45. doi: DOI 10.1007/s10943-013-9781-3

Sukmadinata, N. S. (2005). Metode penelitian pendidikan: Program Pascasarjana Universitas Pendidikan Indonesia dengan PT Remaja .

Syafri, F. S. (2017). Ada Apa dengan Kecemasan Matematika? Journal of Medives: Journal of Mathematics Education IKIP Veteran Semarang, 1(1), 59-65.

Zakiyyah, A. (2017). Hubungan religiusitas dan persepsi siswa terhadap guru dengan kecemasan menghadapi pelajaran matematika. UIN Sunan Ampel Surabaya. 